\title{
Mind Is Reality: Buddhism Is Not a Pessimistic Religion
}

\author{
Yan Shi \\ Chinese Department, College of the Humanities, Xiamen University, Xiamen, China \\ Email: shiyanxm@xmu.edu.cn
}

How to cite this paper: Shi, Y. (2016) Mind Is Reality: Buddhism Is Not a Pessimistic Religion. Open Journal of Social Sciences, 4, 28-38.

http://dx.doi.org/10.4236/jss.2016.410003

Received: August 19, 2016

Accepted: October 14, 2016

Published: October 17, 2016

Copyright $\odot 2016$ by author and Scientific Research Publishing Inc. This work is licensed under the Creative Commons Attribution International License (CC BY 4.0).

http://creativecommons.org/licenses/by/4.0/

\begin{abstract}
The main body of this essay was divided into two parts, with the first one-to controvert the misunderstanding that "Buddhism is a pessimistic religion" and to point out that Buddhism was neither pessimistic nor optimistic but realistic, and the second one-to focus on the topic of nature of mind and to give reasons why Buddhism, especially Ch'an (Zen) Buddhism, said that "Mind is reality".
\end{abstract}

\section{Keywords}

Mind, Reality, Ch'an (Zen) Buddhism, Religion

\section{Introduction}

Nowadays, people all over the world are getting more and more interested in Buddhism. Numerous societies and study-groups have emerged, and scores of books on the teachings of the Buddha have appeared. One of the basic issues of Buddhism is the nature of mind, and to understand Buddhism, it is thus necessary to have an in-depth study of this subject. What is the nature of mind? Just because of thoughtless understanding on this very question, some people were of the opinion that Buddhism was unscientific and superstitious, and that as a religion, it was completely based on Theology, and apart from its moral teaching, there was not much content to it. Others said that its theory, admittedly profound, was too idealistic, impractical and not worth learning. Indeed, there is much misunderstanding around the world with regard to Buddhism. However, in view of the continual existence of Buddhism in the past two thousand five hundred years and its prevalence in certain parts of Asia at different intervals, I strongly believe that it is clear that its unique value does not lie in religious worship, or else it would have declined and disappeared from human civilization long ago [1]. 
In this essay, I am going to divide the main body into two parts, with the first one-to controvert the misunderstanding that "Buddhism is a pessimistic religion" and to point out that Buddhism is neither pessimistic nor optimistic but realistic, and the second one-to focus on the topic of nature of mind and to give reasons why Buddhism, especially Ch'an (Zen) Buddhism, says that "Mind is reality".

\section{Is Buddhism a Pessimistic Religion}

A common mis-conception about Buddhism is that "Buddhism is a pessimistic religion". This erroneous criticism is an outcome of misunderstandings mainly from three aspects: 1) misunderstanding of the true meaning of Dukkha from the Buddhist perspective; 2) misunderstanding of how Buddhists (Buddhist monks and Buddhist laity) behave; 3) misunderstanding that Buddhism is a religion. In this part, I will refute these three misunderstandings with basic Buddhist theories, and explain why Buddhism is NOT a pessimistic religion. This part comprises three sections: 1) The True Meaning of Dukkha from the Buddhist Perspective; 2) A True Buddhist Is the Happiest of All Beings; 3) Buddhism Is More an Educational Doctrine than a Religion. Finally, the thesis that Buddhism is neither pessimistic nor optimistic but realistic will be given.

\subsection{The True Meaning of Dukkha from the Buddhist Perspective}

\subsubsection{Life Is Not Only Suffering}

The focal point of the Buddha's teaching lies in the Four Noble Truths (Cattāri Ariyasaccāni), which are: Dukkha, Samudaya (the arising or origin of dukkha), Nirodha (the cessation of dukkha), and Magga (the way leading to the cessation of dukkha). The Pali word dukkha (or Sanskrit duhkha) usually means "suffering", "pain", "sorrow" or "misery". It is true that in ordinary usage dukkha is opposed to the word sukha, which means "happiness", "comfort" or "ease". But nearly all Buddhist classics and scriptures trust that as a key element of the First Noble Truths, the term dukkha in the Buddha's view of life and of the world has a deeper and more philosophical meaning. Besides the ordinary meaning of "suffering", the term dukkha in the First Noble Truth also contains qualities such as "imperfection", "impermanence", "emptiness", and "insubstantiality". However, many scholars have called the First Noble Truth as "The Noble Truth of Suffering" and interpreted it in the way that life according to Buddhism is nothing but suffering and pain. Neither the naming nor the interpretation is satisfactory, and both of them are highly misleading. Just because of this inadequate and harebrained translation and its superficial explanation, many people have been misled into regarding Buddhism as pessimistic. This is why some researchers have insisted on leaving the term untranslated, rather than turning it into a convenient translation with inadequate and erroneous connotation [2].

It is unquestionable that no one, rich or poor, strong or weak, intelligent or foolish, can avoid suffering, which is clearly universal: parting with the beloved, meeting the hated and undesired, illnesses, unfulfilled wishes, broken love, vicissitudes of life's fortune, etc. In life there are hundreds of afflictions that both undermine the body and 
trouble the mind. Clearly, even in the short span of life there is always a lot of suffering and sorrow [1]. When the Buddha says there is suffering in life, he does not deny happiness. On the contrary, he admits the value of different forms of happiness for laymen as well as for monks, on both material and spiritual levels, such as the happiness of family life, that of pleasures of sensation and of renunciation and so on. Nevertheless, all these are actually dukkha in disguise [2]. Some may argue that they have never known suffering in their lifetime, but this is not true. Dukkha is universal. People are unaware of it merely because they are so used to it for so long that they take it for granted.

As the Buddha says, "he who sees dukkha sees also the arising of dukkha, sees also the cessation of dukkha, and sees also the path leading to the cessation of dukkha" [2]. This does not make the life of a Buddhist melancholy or sorrowful at all, as some people wrongly imagine. According to Buddhism, all kinds of suffering are but reactions of the mind, and both their arising and cessation are separately brought about by the mind. If the mind does not create any karma, consequently there will be no trans-migration or reincarnation, and neither will there be any suffering at all (according to Buddhism, the force of all perverted activities of the body, speech and mind caused by delusions in Buddhist terms called "Karma". And according to the causal vehicle, karma is the activity of cause and result. According to the resultant vehicle, it is unnecessary to divide cause from result.) [3]. When in delusion, unknowingly the mind becomes discriminating and automatically generate karma, hence a Buddhist dictum: "Because of delusion, there is Karma and because of Karma, there is suffering" [1]. As Buddhism tells us, although there is suffering in life, one who believes Buddhism should not be gloomy over it, and neither should one be angry or impatient about it. At the beginning we should grapple with the question of suffering with good understanding and deal with it fearlessly and patiently, and once our bias and subjective thoughts about the phenomena before us are wiped out, suffering would be turned into happiness. From this, it can be seen that the Buddhist outlook of the universe and human life is active, positive, complete and universal.

\subsubsection{The World Is Not the Source of Evil and Suffering for Man}

It is a common fallacy that the Buddhists see the world as bad and the source of evil and suffering. In fact, the Buddha never claimed that this world is purely evil, or that sentient beings are objectively evil. According to Buddhism, the source of evil is not the world, but our dualistic mind, or the ego-grasping mind, and that the world is only a reflection of one's mind [3].

In Chan (Zen) Buddhism, the Sixth patriarch Hui Neng once said:

"As the mind arises, so arise all kinds of phenomena; as the mind becomes extinct, so do all kinds of phenomena become extinct. Without the arising of mind, nothing will be at fault" [4].

Similarly, in the Agama, it says that "all phenomena are one, and the one phenomenon is the mind that gives rise to all phenomena" [5]. And the Avatamsaka Sutra also states that: 
"The three world-spheres are an illusion created by the mind".

"If people want to know about the Buddhas of the past, present and future, they should contemplate on the nature of the phenomenal world and then they would realize that everything is created by the mind" [6].

All these scriptures tell us that the "mind" is the creator of the universe and our existence comes from it. When our selfish mind takes control of us, it will directly influence our interpretations of the world and affect the way we act on the world. Directed by the selfish mind, when something is beneficial to us, we will wish to obtain it, thus giving rise to greed. With a hateful mind, hatred arises when someone takes away what we like. With a jealous mind, jealousness arises when others are more fortunate or stronger than us. The more our mind is defiled by greed, hatred, and delusion, the less we can see the reality of the world and the easier for us to deduce that the world is bad and evil. Therefore, from the Buddhist perspective, whatever considered to be bad in the world comes from the deluded minds of sentient beings who created it from their own habits. Although Buddhism holds that sentient beings with deluded perception would experience suffering, it does not call the world evil [3]. On the contrary, it sees that it is possible for the continuous suffering of this delusion to cease since each being has the potential to recognize the cause and result of suffering, and then transform this suffering into happiness and peace. In short, to depart from suffering means the removal of a deluded mind.

\subsection{A True Buddhist Is the Happiest of All Beings}

\subsubsection{A True Buddhist Is Not a Negative and Pessimistic Escapist}

In Buddhism there is no other concept as difficult to explain or to make believe as the question of Reincarnation and Transmigration. According to Buddhism, all living beings of this world are subject to rounds of birth and death, life after life, in different states of existence. Such phenomenon is called "reincarnation" or "transmigration" (samsāra) [7]. Because of "karma", which is interlocked with a series of causes and effects operating incessantly at all times, and because of the very complex formation and development of karmic elements, there are as many as six different states of transmigratory existence-devas, asuras, human beings, ghosts, animals and hell beings-where the wheel of reincarnation turns on and on until dukkha is completely eliminated. The emancipation, liberation, freedom from suffering, from the continuity of dukkha, is known as Nibbanna in Buddhism, as stated by the Noble Truth of the Cessation of dukkha [2].

Many people have the wrong belief that transmigration and Nibbāna are negative and equivalent to self-annihilation. In order to achieve Nibbāna, a Buddhist (a Buddhist monk or a Buddhist laity) must behave like an escapist. To liberate himself from suffering, he must keep himself far from this world and break his ties with other peopleties existing in human nature, human psyche, and human bodies, as if the more he is liberated from these ties, the more he would become indifferent to what is in the world, and the more he would be free from suffering. To say this and assert that "a Buddhist is 
a negative and pessimistic escapist" is wrong and untrue.

As a matter of fact, Buddhists have to care for their basic wants and to work for their living every day just like other human beings. Not only should they live with a remarkable self-reliant spirit, they should also cultivate awareness incessantly in everyday life so as to prevent themselves from going wrong and to free themselves from all suffering. This can be shown clearly in the following Buddhist dictums [1]:

"No work for the day, no food for the day".

"Buddhism is inseparable from the world but also aware of the world".

"Buddhism lies nowhere but rightfully in the phenomena of the universe".

"Speech and undertakings beneficial to others and necessary for maintaining one's own living are in accord with Buddhism".

Furthermore, Buddhists should never be away from sentient beings no matter where they are. The Buddha teaches all his disciples to be always in close touch with sentient beings and not to forsake them on any account, as The Avatamsaka Sutra says:

"If there are no sentient beings, no Bodhisattva will ever attain Supreme Perfect Enlightenment".

The dictum from The Vimalakirti-nirdesa Sutra, "to be at the service of sentient beings with all humility", shows clearly that in Buddhism the spirit of self-sacrifice and rendering service to others is of fundamental importance. A true Buddhist is therefore definitely not a negative and pessimistic escapist. How can one claim that Buddhism is unrelated to life?

\subsubsection{A True Buddhist Goes More than Moral Preaching}

It is paradoxical to pass the criticism on Buddhism that Buddhists merely urge people to do well. In fact the fundamental thing of Buddhism is that, in one hand it teaches people to practise virtues, and in the other hand it teaches people not to abide in the virtues. In other words, to attain enlightenment, every good act should be carried out in the spirit of "selflessness". Otherwise enlightenment can never be achieved.

The episode about Bodhidharma's first interview with Emperor $\mathrm{Wu}$ of the Liang Dynasty is well known by many. Bodhidharma was asked by the Emperor what merits the latter would get for his work in building temples, allowing new monks to be ordained (royal consent was necessary at that time), giving alms and entertaining the Order. His reply was that these would bring no merits at all [6]. Why did Bodhidharma give such an answer? The explanation made by the Sixth Patriarch Hui Neng was:

"Emperor Wu's mind was under an erroneous impression... The deeds as building temples, allowing new monks to be ordained, giving alms and entertaining the Order will bring you only felicities, which should not be taken for merits. Merits are to be found within the Dharmakaya, and they have nothing to do with practices for attaining felicities $\cdots$ He who is in the habit of looking down upon others has not got rid of the erroneous idea of a self, which indicates his lack of Gong (good deserts). Because of his egotism and his habitual contempt for all others, he knows 
not the real Essence of Mind; and this shows his lack of De (good quality) $\cdots$ When our mental activity works without interruption, then it is Gong; and when our mind functions in a straightforward manner, then it is De" [8].

It is a pity that this lofty principle of "selflessness" of Buddhism is rather difficult for the average men to grasp and understand. That is why they miscounted the Buddhists as melancholy or gloomy ones.

\subsection{Buddhism Is More an Educational Doctrine than a Religion}

Is Buddhism a religion or a philosophy? This is a question often asked. According to the Webster's Dictionary, the word "religion" is defined as "An organized system of beliefs, rites, and celebrations centered on a supernatural being power; belief pursued with devotion" [9]. Some people insist that the Buddha is such a "supernatural being" with the same concept as the so called "Creator God" in some religion who has the highest authority over everyone and everything. Based on such a wrong view, some educe unreasonably that all suffering and sorrow are created by the Buddha or the Bodhisattvas, and that a human being can never change his destiny and make himself live a happier life. Even worse, many superstitious beliefs and practices in connection with demons and spirits have been wrongly attributed to be something of Buddhism. As a result, not only the truth of Buddhism is obscured but the understanding of Buddhism is also badly distorted [1].

In fact, both Buddhas and Bodhisattvas are in the same category of Buddhists. The only difference between them and ordinary Buddhists is that they are at different levels of awareness. The Buddha did not claim that he was a god, or the child of a god or the messenger of a god [10]. He is simply a person who has achieved complete understanding of the reality of life and the universe. Meanwhile, Buddhas and Bodhisattvas all practise the Dharma to benefit others as well as themselves and, in the spirit of self-abnegation, dedicate themselves to serve sentient beings and the mankind. Moreover, the Buddha taught that all beings can become Buddhas. All beings possess the same ability within to achieve complete understanding of themselves and their environment and to free themselves from all sufferings and attain utmost happiness. Buddhism is a rational belief, pure and simple, and may also be said to be a living practical knowledge of empirical metaphysics [1]. Consequently, one can see the Buddha not as a God but as a teacher, and one can also see Buddhism not as a religion but as an educational doctrine.

Buddhism is not a pessimistic religion at all. As a matter of fact, Buddhism is a rational belief but not superstition. It is not out of touch with the world, but in and beyond the world. Rather than serving to benefit oneself alone, a Buddhist serves to benefit others as well. Because of this, Buddhism has been able to stand firmly in the world for over two thousand years and carry on its great work unceasingly and continually to the present day.

The dictionary defines the word "pessimism" as "the habit of thinking that whatever will happen will be bad," or "the belief that evil is more powerful than good" [10]. 
Buddhism teaches neither of these ideas. Nor does Buddhism deny that happiness exists. In conducting daily affairs, Buddhism is capable of exerting tremendous beneficial influences, and as a result, a great, positive, bright and happy life, embodying the spirit of true freedom and equality, can be realized.

\section{What Is the Nature of Mind?}

The second part of this essay will be divided into four sections, with the first one-The Importance of Mind-addressing the question of mind and the significance of examining the characteristics of mind for grasping the meaning of its true-nature, the second one-Mind and Phenomena-giving a framework of the interrelationship between mind and the phenomena of the universe with some fundamental Buddhists concepts as reference, the third one-Mind and Things-investigating how mind and everything around us mutually emerge and manifest through the existence of each other, and finally the fourth one-Illusion and Reality, Illusory Mind and True Mind.

\subsection{The Importance of Mind}

Not only in Buddhism but also for ages the "mind" has been a controversial subject among thinkers all over the world. What philosophers and psychologists have probed so far only deals with the question of mind, yet many other issues (of mind) still left unexplored, among those the most prominent one is about the nature of mind. Mind, together with thought and volition, plays an important role in all aspects of the development and progress of every community. It is in this sense that Psychology may rightly claim to be the major study of man. In reality, there is no basic knowledge more important than the fundamental Dharma that helps us to understand our mind and realize its self-nature. On one hand, for us to attain such understanding and realization is as important as capital for business and food and fuel for cooking [1]. On the other hand, one who does not understand the nature of mind is just like a blind man going the wrong direction and surely would fall into subjective thinking though he may be totally unaware of doing so.

\subsection{Mind and Phenomena}

The Sixth patriarch Hui Neng said:

"As the mind arises, so arise all kinds of phenomena; as the mind becomes extinct, so do all kinds of phenomena become extinct. Without the arising of mind, nothing will be at fault".

Similarly, in the Agama it says that "all phenomena are one, and the one phenomenon is the mind that gives rise to all phenomena". And the Avatamsaka Sutra also states like:

"If people want to know about the Buddhas of the past, present and future, they should contemplate on the nature of the phenomenal world and then they would realize that everything is created by the mind". 
All of these scriptures tell us that "mind" is the creator of the universe and our existence comes from it. In order to understand this, we have to firstly find out the interrelationships between mind and phenomena of the universe. Some fundamental concepts of Buddhism must be discussed first and they are as the followings [6].

\subsubsection{The Law of Dependent (Conditioned) Origination}

All things of the universe, as a matter of fact, undergo moment-to-moment changes from their creation to extinction, with transformation taking place continually and unceasingly. This includes phenomena of objective material things and phenomena of subjective thoughts. Therefore, all phenomena before us are nothing but parts of the "Sum-total of the ever-continuous, ever-recurring phenomenal transformations of the universe". Meanwhile, in the course of the development of each phase of creation, extinction and transformation, not only every phenomenon and its surrounding phenomena are interrelated with each other, but each of which mutually influences the other one as well. As a result, they bring about a "network of closely-knit and interlocked cause-and effect relationships" [1]. In Buddhism, the law which deals with the working of the interrelationships of the cosmic phenomena in this manner is called "The Law of Dependent (Conditioned) Origination". In other words, all things and phenomena in the world are connected with, dependent on and conditioned by one another. So it is said in one Buddhist scripture:

"When this is, that is; This arising, that arises; When this is not, that is not; This ceasing, that ceases" [2].

In short, causes and effects go on forever, there is no beginning and there is no end.

\subsubsection{All Conditioned Things Are Impermanent}

This Buddhist dictum means that everything tends to change and nothing is fixed and immutable. Based on "the Law of Dependent (Conditioned) Origination", which depicts the world as made up of causes and effects, it follows that nothing in the world is permanent. Every phenomenon is causally produced, and its destruction or transformation is also naturally brought about by causation. This explains how the sequence of "formation, existence, destruction and void" works out in this world; how living beings have to undergo "birth, age, illness and death" in their lifetime; and in the realm of thought, how the sequence of "arising, staying, changing and vanishing" is to come about [1]. Everything is transient. Just as pictures are drawn by artists, real, stable things and their surrounding are created by the mind. The mind considers something good and some other things bad, yet in fact there is no such distinction. For instance, the process of life and the process of death are the same. What is called the east is also the west [4]. This is exactly how the Avatamsaka Sutra describes:

"Like a skilful painter who is unable to know his own mind and yet can paint because of his mind, so is the nature of all phenomena. The mind is the skilful artist who can paint the different worlds. As the Five Aggregates accordingly emerge, there is nothing that cannot be created" [6]. 


\subsubsection{All Forms (Phenomena) are Unreal and Illusory}

In the Diamond Sutra, it says: "All forms (phenomena) are unreal and illusory". From what we have discussed in the aforesaid, this is not hard to understand. Since all phenomena are produced by causes, they are transient and impermanent, and so they are illusory and unreal. Nevertheless, they are not non-existent for the sequence of their creation although they are illusory. Development and extinction always operate alternately and continually in succession, and that's why Buddhism says that there is only "extinction by mutation" but there is no "total and complete extinction" [1]. Take a very famous Ch'an episode as an example. Back in Guangdong, the Sixth Patriarch Hui Neng lived a secluded life in the mountains for many years. Then one day, when he was 39 years old, he went to a temple to listen to the learned abbot's explanation of Buddhism. Two monks were arguing on the fluttering of a canopy. One said, "The canopy is fluttering," and the other said, "The wind is fluttering the canopy." Hui Neng interrupted them by saying, "Neither the canopy nor the wind is moving. It is your own mind that is moving" [4]. In this episode, we must remember that Master Hui Neng did not negate the actual movement of the wind and canopy, but only emphasized on the important influence of mind in the world we know. Wind and canopy are the externalities, one of the necessary conditions. But without the presence of mind or consciousness, the presence of wind and the canopy would not have been known, not to mention whether they had moved. That is why Master Hui Neng pointed out that "It is your own mind that is moving" to demonstrate the crucial role of the mind in worldly existence and to awaken the monks to their lack of insight, and this is exactly the perception of the important function of the mind in the arising of all phenomena.

\subsection{Mind and Things}

From the standpoint of Buddhism, mind and things are two indivisible aspects of one complete and perfect entity. The saying "because of things, there is mind" points to the presence of the Sixth Consciousness, for example, at the sight of a cup, its image is formed in the mind at once; inversely speaking, "because of mind, things are manifestable" tells us that although the cup is objectively present, "one may look but may not see when the mind is not on the object"; in the case of a Buddhist adept who is able to transmute consciousness into wisdom, the mind is used to be detached from things and objective projections of the mind, and so the saying "because of mind, things are manifestable" shows how under such condition, the subjective mind, or rather the sixth consciousness, is actively at work. From this, we can see that things are where mind is, and mind is where things are; inversely speaking, apart from the mind, nothing exists, and apart from things, there is no mind; thus it may be concluded that mind and things are no duality at all (according to Buddhism, mind may be divided into Eight Consciousness which are Eye Consciousness, Ear Consciousness, Nose Consciousness, Tongue Consciousness, Body Consciousness, the Sixth Consciousness [Sense-centre Consciousness], the Seventh Consciousness [Manas], and the Eighth Consciousness [Alaya]) [1].

Because of this, it is believed that the feeling of happiness and suffering are not real, 
and it is the mental attitude that determines the way we feel. "What kind of life we lead depends on what attitude of mind we possess". It is why at the heart of Buddhist practice, one trains the mind until it becomes nonattached with regard to external conditions but more like their master. When this state of being is attained, we would remain calm and relaxed in difficult times.

\subsection{Illusion and Reality; Illusory Mind and True Mind}

In daily life, our mind is subject to be conditioned all the time. It may become happy, unhappy, angry or greedy all suddenly, and it is named as deluded mind or illusory mind which comes and goes momentarily, continually and alternately. It includes feeling, impression, conception, consciousness and so forth. This kind of mind is not the so-called "Self-Nature". Only the "True Mind" has the same meaning with "Self-Nature"

[1]. To use a metaphor, supposing we throw a stone into some stationary water, immediately waves emerge and apparently start to travel outwards from the centre of the disturbance. The waves traveling outwards are of course an optical illusion, caused by the up-and-down movements of the water particles in a certain pattern. Illusion and deception set in as soon as we consider that the waves have an existence separate from the water, or the "experiences" as being different from the "experiencer", instead of realizing that the waves are the water, the experiences and the experiencer are one. As the water manufactures the optical illusion of the waves, an illusory mind creates the illusion of the thinker [5]. So "illusory mind" is to "true mind" as is wave to water, and "true mind" is the fountainhead of all thoughts, concepts and other phenomena of the mind [1]. To this extent, the conventional ways of describing reality are "unreal", "implausible", "insufficient", or "inaccurate". Only when we understand the mind and realize the self-nature then it is possible for us to see the world as it really is.

\section{Conclusions}

In conclusion, the Buddhist saying "Everything is created by the mind" does not negate the existence of worldly phenomena. Meanwhile, the Buddhist perspective emphasizes that our illusory mind creates a world that is self-centered and illusive. On the other hand, a pure or uncorrupted mind is capable of seeing the world as it really is. As Ch'an Buddhism puts it, an enlightened mind that can realize the ultimate reality of the nature of mind is conducive to "understanding the mind and realizing the self-nature". Once the mind is enlightened, instantaneously the "True Mind" is also realized.

It is wrong to say that Buddhism is pessimistic. Nevertheless, to say that Buddhism is optimistic is not correct either. Buddhism is neither pessimistic nor optimistic. It is realistic. The book What the Buddha Taught has a paragraph which I think is appropriate to be the conclusion of my essay:

“... It (Buddhism) takes a realistic view of life and of the world. It looks at things

objectively (Yathābhütam). It does not falsely lull you into living in a fool's para-

dise, nor does it frighten and agonize you with all kinds of imaginary fears and

sins. It tells you exactly and objectively what you are and what the world around 
you is, and shows you the way to perfect freedom, peace, tranquility and happiness" [2].

\section{References}

[1] Chi, H.H. (1985) What Is Buddhism? Theory and Practice. English Translation by P. H. Wei, Hong Kong Buddhist Books Distributor, Hong Kong, Complimentary Dharma Series No. 13, 1-30.

[2] Rahula, W. (1974) What the Buddha Taught. Grove Press, New York, 16-53.

[3] Norbu, T. (1998) Welcoming Flowers: From across the Cleansed Threshold of Hope: An Answer to the Pope's Criticism of Buddhism. Chinese Version Translated by Chen Nianxuan, Zhong Sheng Wen Hua Publication, Taibei, 11-16, 45.

[4] Ding, W.D. (2001) Glimpses of Chinese Culture. Foreign Language Teaching and Research Press, Beijing, 84, 105.

[5] Powell, R. (1977) Zen and Reality: An Approach to Sanity and Happiness on a Non-Sectarian Basis. Penguin Books, New York, 57.

[6] Yin, J. (2008) Harmony in Society Begins with Our Own Mind. Lecture Notes of "CHIN0001 Making Sense of Ch'an (Zen)”, The University of Hong Kong, 2-12, 20.

[7] Nyanatiloka (2006) Buddhism Dictionary: Manual of Buddhist Terms and Doctrines. Singapore Buddhist Meditation Centre, Singapore, 160.

[8] Lam, W.K. (2004) Merits or No Merits?-The Case of Emperor Wu, The Buddhing Lotus. Vol. 1, Edited by Jing, Y., CBS HKU, Hong Kong, 152-158.

[9] China Kung (2000) A Path to True Happiness. Buddhist Youth Association, Hong Kong, 8.

[10] Dhammika, S. (2000) Good Question Good Answer. Buddhist Youth Association, Hong Kong, 3-14.

Submit or recommend next manuscript to SCIRP and we will provide best service for you:

Accepting pre-submission inquiries through Email, Facebook, LinkedIn, Twitter, etc. A wide selection of journals (inclusive of 9 subjects, more than 200 journals)

Providing 24-hour high-quality service

User-friendly online submission system

Fair and swift peer-review system

Efficient typesetting and proofreading procedure

Display of the result of downloads and visits, as well as the number of cited articles

Maximum dissemination of your research work

Submit your manuscript at: http://papersubmission.scirp.org/

Or contact jss@scirp.org 